\title{
Profile of Teaching Materials Environment Biology and Ability Pre-service Biology Teacher to Communicate Laboratory Report
}

\author{
Ahmad Yani ${ }^{1,2}$, Mohamad Amin ${ }^{3 *}$, Fatchur Rohman ${ }^{3}$, Endang Suarsini ${ }^{3}$, Sahriah $^{2}$ \\ ${ }^{1}$ Postgraduate Program, Department of Biology Education, Universitas Negeri Malang, Indonesia \\ ${ }^{2}$ Biology Education Program, Faculty of Teacher Training and Education, Universitas Puangrimaggalatung \\ Sengkang, South Sulawesi, Indonesia
}

${ }^{3}$ Department of Biology, Faculty of Mathematics and Natural Sciences, Universitas Negeri Malang, Indonesia

*Corresponding Author: Ahmad Yani, Department of Biology, Faculty of Mathematics and Natural Sciences, Universitas Negeri Malang, Indonesia.

\begin{abstract}
This research is a descriptive study to determine the profile of teaching materials and the ability of pre-service teacher to convey the results of the placement at the University of Puangrimaggalatung (UNIPRIMA) Sengkang in environmental biology subjects. The study's population consisted of undergraduate pre-service teacher in the third semester of the 2016/2017 academic year and lecturer of environmental biology subjects. The sampling technique was carried out by targeted sampling so that 37 subjects were used. Techniques for collecting interviews and observations. The tool, which was used in the form of interview guidelines to find out the profile of the teaching materials used, reported the practice assessment of practicerelated reports to determine the ability to communicate the results of laboratory report. The data were analyzed descriptively. Based on the results of the study of teaching materials used in the matter, it needs to be developed/produced again and still needs to be done through the development of research and context teaching materials. The ability of pre-service teacher to communicate the results of the work placement in lab reports is still considered sufficient and needs to be improved again, especially with regard to the accuracy of the analysis of data findings and the relevance of the theory in the analysis of experimental data.
\end{abstract}

Keywords: Communicate, Laboratory Report, Teaching Materials,

\section{INTRODUCTION}

Cognitive performance is not the only priority in learning, especially at universities. Based on the Indonesian National Qualifications Framework (KKNI) for Strata 1 (S1), the Level 6 learning outcome (LO), which is able to apply studies, design, use of science and technology, solves problems [1]. To realize the LO based on the KKNI, learning should include interconnected components to achieve a predetermined goal [2]. Part of learning is goals, materials, methods, media, and assessments that can be packaged in educational materials [3].

Teaching materials are tools that can help teachers and pre-service teacher in the teaching and learning process [4] and can be used to overcome the difficulties of learning from pre-service teacher [5]. Currently, teaching materials compiled by some teachers and lecturers have no relation to the context, to the state of the students [6], and not to research purposes [7], thus affecting pre-service teacher ' low interest and motivation in the learning process [8]. The learning process in higher education is generally done by assigning tasks, discussions and creating papers, which are then presented to the class. If you learn that only cognitive aspects have priority, this will affect the lack of optimization of student skills in the lecture process [9].

Teaching materials used by teachers and faculty members should convey and provide information, stimulate student interest, and facilitate the learning process (Igua et al., 2014). Teaching materials in a scientific discipline or knowledge can be used as learning resources or learning media [7], as a teaching tool, teaching materials must include teaching material on how to present teaching materials and models to improve pre-service teacher ' cognitive [2], [4] and psychomotor skills [10]. This is in line with what has been shown by Abdulraheem \& Amali, (2013) that there is a significant correlation between the use of teaching material and student performance, so teaching material is an important 
learning element, as it can act as learning resources and contain material which is dominated by the pre-service teacher of course [6]. In addition to the teaching material, learning strategies are one of the factors for learning success [2].

Learning with specific strategies can offer active pre-service teacher the opportunity to develop concepts, insights, and new knowledge based on facts, information, and knowledge they previously owned [12]. Biological learning has to come in stages where pre-service teacher can solve problems based on the problems of everyday life [13], subsequently, experiments or practices are carried out to formulate concepts and apply them to new concepts that enable the framework to study science and dispute [14]. Practical activities are an integral part of the learning process and can be used to: to develop complete competences in cognitive, affective and psychomotor aspects in pre-service teacher [13]. In addition, hands-on activities can give pre-service teacher the ability to argue or communicate in practical reports [6]. Therefore, communication skills are part of the scientific process competencies that must be acquired and trained by biology education pre-service teacher to develop the pre-service teacher ' potential in a course [15].

Things that cannot be separated from practical activities are writing reports, and pre-service teacher are required to write reports to enable pre-service teacher to do practical activities, they can be used as a forum for pre-service teacher to develop communication skills in the written language [16]. According to Kholifudin, (2014), the ability to communicate the results of the placement/experiment is required by the pre-service teacher so that what they have achieved can be passed on to others and as a form of dissemination. However, based on the results of the study [15] from several indicators, the report's ability to communicate is still considered sufficient in the report and needs to be trained to draw conclusions.

The Environmental Biology course is one of the compulsory subjects of the UNIPRIMA Sengkang Indonesia biology class with a 2-point grade in the third semester. Learning Outcomes (LO) from the course are pre-service teacher who are capable of understanding the environment, environmental issues, the population and its problems, environmental principles, natural resources, pollution, health and the environment, and development strategies to understand the environment (biology curriculum) 2014). One of the materials described in this course is water pollution and efforts to overcome it. Water pollution is the biggest problem in many developing countries, caused by waste such as domestic, agricultural and industrial waste [18]. Waste management is a problem faced by all countries due to the growing population, high density and industry. In addition, population and industrial waste are rising in the form of solid, liquid or gaseous waste that can pollute waters such as rivers and lakes [19]. Therefore, this material is considered necessary to be integrated into learning using current topics and contextual learning. Pre-service teacher are also expected to understand the importance of environmental education and control efforts through the application of bioremediation biotechnology.

Based on the LO of the Environmental Biology course, it can be seen that the achievement of the subjects did not meet the KKNI standard at level 6, as the learning content of this course is pre-service teacher ' ability to understand only the concept of formulating procedural problems, concepts apply and not apply science and technology to topics Current problems related to the environment and the problems. In order to present three aspects, namely the mind, the practice and the heart of the lecture process of environmental biology, it is necessary to use learning strategies that are relevant to the topic of learning and to provide learning resources in the form of research-based books. For researchbased learning aims to help pre-service teacher improve and develop their skills, especially those related to scientific process skills [20]. The development of research-based textbooks is one of the activities that can broaden and deepen the material application-related [21]. Research results integrated into teaching materials are effectively used for learning because they are more applicable and correspond to actual elements [22]. Textbooks are books that contain a scholarly analysis of the curriculum in writing (Ministry of National Education, 2008). Another function of textbooks is to provide learning opportunities for both content and presentation [23]. This study aims to analyze the need to develop educational materials on environmental biology for pre-service teacher of the graduated Biology Education Program at UNIPRIMA Sengkang Indonesia. In addition, this study will provide an overview of the pre-service teacher' ability to communicate the results of exercises/essays in the laboratory report. 


\section{Materials AND Methods}

This study is a descriptive study conducted at UNIPRIMA Sengkang Indonesia from February to May 2017. The population of the study consisted of pre-service teacher of biology education 2016/2017 and lecturers in environmental biology. The sample used in this study, which had passed the Environmental Biology course, was 87 pre-service teacher. The sampling technique was carried out by targeted sampling so that the study in this study consisted of 37 pre-service teacher. Data collection techniques through observation and interviews to obtain profiles of educational materials used during the lecture process and the format of the internship report produced by pre-service teacher in environmental biology practical environmental activities. The tool was used in the form of an interview guide to find out the profile of teaching materials used by faculty. The assessment section consists of criteria for the experimental report/preliminary study describing pre-service teacher' ability to communicate the results of the laboratory report. The criteria for the assessment of the internship by [15] include: 1) clarity of practical work processes; 2) the ability to process findings correctly; 3 ) accuracy of the analysis of the findings data; 4) consistency with goals, outcomes and conclusions; 5) relevance of the theory in the analysis of entrepreneurial data; 6) systemic accuracy of the report; 7) Timeliness of reporting. The evaluation of laboratory reports was descriptively analyzed by means of a number of evaluation scales (1-3) using communication capability indicators. The data were analyzed descriptively.

\section{RESULTS \& DISCUSSION}

\subsection{Results}

\subsubsection{Description of Teaching Materials for Environmental Biology}

Based on the results of the interviews with the professors of the Environmental Biology course, the information was received that the lecture process Environmental Biology had used teaching materials, which however had to be refined or further developed. The learning resources they use are composed only by lecturers who do not use the Internet (blogs and Wikipedia), journals and e-books and international references as reference sources. In fact, learning resources can be built from multiple references and based on research [24]. As a result, pre-service teacher only understand theoretical concepts, learning resources are very limited, and other scientific skills are incapable. Thus it affects the completeness/cognitive performance level of pre-service teacher between 50\% and 79\%. This is consistent with the statements of Yani \& Adiansyah (2017); Yani, Tahmir, et al. (2017), developing lesson materials, such as modules, based on a learning model/approach can improve pre-service teacher ' learning outcomes.

Cognitive transmission is not only an evaluation aspect, but there are still effective and psychomotor aspects. In psychomotor aspects of learning, environmental biology is carried out by assessing preservice teacher ' activities, namely, identifying pollution in rivers and lakes, testing river and lake water quality ( $\mathrm{pH}$, temperature, turbidity \& DO). The lecture process does not optimize the use of the environment as a learning resource or does not fully utilize contextual learning. According to Kholifudin (2014), research-based learning through hands-on activities will support pre-service teacher ' scientific process capabilities and academic attitudes as a basis for providing pre-service teacher with simple or complex research in their daily lives. In this study, however, only one indicator of scientific ability is developed, namely the ability to communicate in the form of laboratory reports.

\subsubsection{Ability to Communicate Practicum Results in Laboratory Report}

The ability to communicate internship results in lab reports is shown in Table 1. Based on a set of indicators that assess pre-service teacher ' ability to communicate reports on the results of the placement in the Environmental Biology course, it can be seen that the criteria for time recording and clarity of practical work processes have the highest average score and accuracy in terms of accuracy Analysis of the diagnostic data is lowest. However, the average of all Practicum activity has increased from the 1st to the 3rd activity. This is because pre-service teacher receive feedback on each report they collect. So pre-service teacher can find out where the shortcomings of each report have been prepared. 
Profile of Teaching Materials Environment Biology and Ability Pre-service Biology Teacher to Communicate Laboratory Report

Table1. Average Score of Pre-Service Teacher Ability in Communicating Environmental Biology Practicum in Laboratory Report (Writing Language)

\begin{tabular}{|c|c|c|c|c|c|}
\hline \multirow[t]{2}{*}{ No } & \multirow[t]{2}{*}{ Criteria } & \multicolumn{3}{|c|}{$\begin{array}{l}\text { The average score of results } \\
\text { obtained on the practicum to- }\end{array}$} & \multirow[t]{2}{*}{ Average } \\
\hline & & 1 & $\mathbf{2}$ & 3 & \\
\hline 1 & Clarity of working procedure lab work & 2.51 & 2.51 & 2.54 & 2.52 \\
\hline 2 & The ability to process the findings of the findings appropriately & 2.00 & 1.76 & 2.03 & 1.93 \\
\hline 3 & The accuracy of analyzing the findings data & 1.78 & 1.81 & 1.86 & 1.82 \\
\hline 4 & Compliance with the objectives, results and conclusion & 1.84 & 2.03 & 1.95 & 1.94 \\
\hline 5 & Relevance theory in analyzing data experiment & 1.84 & 1.89 & 1.95 & 1.89 \\
\hline 6 & Systematic accuracy of report writing & 2.11 & 2.14 & 2.11 & 2.12 \\
\hline \multirow[t]{2}{*}{7} & Timeliness of report collection & 2.78 & 2.81 & 2.81 & 2.80 \\
\hline & Average & 2.12 & 2.14 & 2.18 & \\
\hline
\end{tabular}

\subsection{Discussion}

On the basis of the results of the research presented, the teaching materials used are assembled independently by lecturers for lectures, the sources of supply are still limited and not compiled on the basis of the research results. They have no special features such as contextual or problem-related, so they still need to be developed. The goals or benefits of developing teaching materials can be achieved. According to Omebe \& Akani (2015), developed teaching materials can help to understand the material more deeply and to make the learning process dance, so that pre-service teacher are more focused on learning, interested and motivated. Another benefit of using classroom materials in Akoni (2016) learning process is the ability to complete oral lessons, make learning more focused, attract student attention, and save time and energy. In addition, the development of teaching materials such as learning modules can improve learning outcomes [4], teaching materials in the form of working groups can improve pre-service teacher ' academic attitudes [6]. According to Bahri (2016), teaching materials are only an indicator of the success of the learning process, namely the achievement of effective, cognitive and psychomotor factors. Another factor that can influence is the selection of learning resources and learning strategies.

The use of the environment as a source of learning is one of the strategies used by UNIPRIMA Sengkang Indonesia lecturers. In addition to the method of discussion, presentation and assignment of tasks for the preparation of lectures on given topics, the pre-service teacher also carry out practical activities in the environment. On the topic of environmental pollution, the pre-service teacher observe the pollutant load and the conditions of the freshwater ecosystems around the campus (rivers, swamps and lakes). Through hands-on activities, pre-service teacher research in groups by examining the quality (temperature, $\mathrm{pH}$, turbidity, $\mathrm{DO}$ and BOD) of river and lake water and analyzing pollution levels. Learning strategies through hands-on activities will enhance science-science skills and laboratory performance [17], [26].

Based on the assessment criteria of the UNIPRIMA Student Report in Table 1. For the criteria for timeliness of reporting and clarity of work, practical activities have increased and have the highest average first and second. This is because pre-service teacher understand the importance of internship reports and there are additional explanations in the internship guide. However, pre-service teacher ' ability to analyze findings data has increased but is not too different from previous practices. This is possible because of the poor understanding of the concept of the pre-service teacher. Based on the assessment of pre-service teacher ' learning outcomes, there are $19 \%$ of pre-service teacher who receive a $\mathrm{C}, 16 \% \mathrm{D}$, and $2 \%$. The overall percentage of pre-service teacher with academic skills is sufficient, low and very low at 37\%. , In accordance with Yuwono (2009) statements, the ability to communicate outcomes had an impact on the ability to understand pre-service teacher ' concepts and to train pre-service teacher to produce and produce scientific reports. Moreover, the reasons for the lack of ability to analyze the results and link the theory to the results of the traineeship are due to the lack of resources to read pre-service teacher in the context of the subjects being studied, and the preservice teacher are not following any scientific developments. Therefore, in the context of the lecture process, environmental biology, in particular, must prioritize three aspects, namely thinking, participating and playing around, using relevant learning strategies for the lecture material, one of which is research-based learning. This is consistent with the research-based learning presented by 
[28], which may encourage pre-service teacher and pre-service teacher to keep abreast of the contextual evolution of science because it is based on research findings.

Data in Table 1. In addition to the description of the average assessment criteria, it can also be seen that the average value achieved in each lab report has increased from internship 1 to internship 3 . The ability of pre-service teacher to communicate the results of the internship is included in the sufficient category. This is because pre-service teacher understand the importance of practice reports. Initially, pre-service teacher have no experience with standardized reporting techniques. The content of the report is still in the form of raw data that is not theoretically supported. In the third internship, the preservice teacher knew the weaknesses of the report prepared by the feedback from the lecturers as a basis for consideration and experience to communicate the results in the laboratory report. According to [15], efforts are being made to improve the pre-service teacher' communication skills through written language through feedback so they can help pre-service teacher through the zone of proximal development to reach the level of intellectual development. Consulting a lecturer will strengthen the relationship between the concepts pre-service teacher have received.

\section{CONClusions}

Based on the explanation of the results and discussion, it can be concluded that: 1) teaching materials used in UNIPRIMA Sengkang Indonesia still need to be improvised or developed; 2) the development of teaching materials in the form of research as much as possible; the scientific process skills of the pre-service teacher can be improved. In addition, an indicator of scientific process capabilities, namely the ability to communicate, from the study's findings indicates that the communication skills of pre-service teacher are still in a sufficient category and need to be improved, in particular as regards data analysis results and theoretical relevance in the analysis of practical data.

\section{ACKNOWLEDGEMENTS}

The author would like to thank the researcher who helped to realize this research. This work was fully supported by Indonesia Endowment Fund for Education (LPDP), Ministry of Research, Technology, and Higher Education of Republic of Indonesia.

\section{REFERENCES}

[1] T. K. Belmawa, "Capaian Pembelajaran Lulusan Program Studi," in Panduan Penyusunan Capaian Pembelajaran Lulusan Program Studi, Jakarta: Dirjen Belmawa Kemenristekdikti, 2014.

[2] D. Maulina and M. Amin, "The Analysis Of Necessity Teaching Materials On Animal Physiology Learning In Lampung University," in Prosiding Seminar Nasional II Tahun 2016, Kerjasama Prodi Pendidikan Biologi FKIP dengan Pusat Studi Lingkungan dan Kependudukan (PSLK) Universitas Muhammadiyah Malang, 2016, pp. 1072-1076.

[3] O. Akoni, "Investigating The Availability And The Extent Of Use Of Instructional Materials By Secondary School Chemistry Teachers In Nigeria,” Int. J. Educ. Learn. Dev., vol. 4, no. 3, pp. 1-11, 2016.

[4] Yani, S. Tahmir, and Muhiddin, "Developing Scientific Approach Based Learning Module in Plantae Concept," in First International Conference on Science, Mathematics, and Education, (ICoMSE 2017) Developing, 2017, vol. 218, no. ICoMSE 2017, pp. 189-194.

[5] A. Omebe and O. Akani, "Laboratory Teaching: Implication On Students' Achievement In Chemistry In Secondary Schools In Ebonyi State Of Nigeria," BEPLS Bull. Env. Pharmacol. Life Sci, vol. 41212, no. 4, pp. 86-94, 2015.

[6] Haerunnisa, A. Yani, and C. Andani, "Pengembangan Bahan Ajar Berbasis Worksheet Matakuliah Biologi Laut untuk Meningkatkan Sikap Ilmiah Mahasiswa,” J. Biotek, vol. 6, no. 2, pp. 96-110, 2018.

[7] D. Maulina et al., "Kajian Kebutuhan Bahan Ajar Matakuliah Biologi Sel di Universitas Lampung," in IsuIsu Kontemporer Sains, Lingkungan, dan Inovasi Pembelajarannya, 2016, pp. 2012-2015.

[8] N. C. N. Igu, F. N. Ogba, and I. O. Igwe, "Effects of Instructional Materials on Students' Achieveme nt in Social Studies in Lower Basic Education in Nigeria," pp. 37-44, 2014.

[9] Yani, Haerunnisa, and S. Rahim, "Analisis Aktivitas dan Sikap Ilmiah Mahasiswa Melalui Model Pembelajaran Project Based Learning (PjBL) Pada Perkuliahan Biologi Air Tawar STKIP Puangrimaggalatung Sengkang Sul-Sel," in Seminar Nasional III 2017 "Biologi, Pembelajaran, dan Lingkungan Hidup Perspektif Interdisipliner", 2017, no. April, pp. 145-150.

[10] Conradty and F. Bogner, "Computer vs. textbook: Effects on motivation and gain in knowledge," Proc. 7th Eur. Conf. e-Learning, ECEL 2008, vol. 1, no. Dl, pp. 231-238, 2008. 
[11] Y. Abdulraheem and A. Amali, "Teachers' Pedagogical Skills and Use of Instructional Materials as Correlate of Students' Performance in Social Studies,” Inst. Univ. Panafricain, vol. 1, no. 1, 2013.

[12] Bahri, "Strategi Pembelajaran Reading Questioning and Answering (RQA) pada Perkuliahan Fisiologi Hewan untuk Meningkatkan Hasil Belajar Kognitif Mahasiswa,” J. Bionature, vol. 17, no. 2, pp. 107-114, 2016.

[13] Yani, Muhsyanur, Sahriah, Haerunnisa, and S. Salmawati, "Efektivitas Pendekatan Saintifik dengan Media Booklet Higher Order Thinking Terhadap Hasil Belajar Biologi Siswa SMA di Kabupaten Wajo," J. Biol. Sci. Educ., vol. 7, no. 1, pp. 2541-1225, 2018.

[14] S. Windyariani and A. Sutisnawati, "Pengembangan Bahan Ajar Berbasis Konteks dan Kreativitas untuk Melatihkan Literasi Sains Siswa Sekolah Dasar,” vol. 4, no. 2, pp. 19-25, 2016.

[15] Y. Astuti and R. Suciati, "Profil Kemampuan Mahasiswa Calon Guru Biologi,” vol. 6, no. 1, pp. 115-124, 2017.

[16] S. Windyarian, "Pembelajaran IPA Dengan Praktikum Berbasis Konteks dan Literasi Sains: Perspektif Guru SD di Sukabumi,” J. Pendidik. Mat. dan IPA, vol. 8, no. 1, pp. 23-33, 2017.

[17] M. Y. Kholifudin, "Profil Pembelajaran Fisika Berbasis Riset Sederhana melalui Praktikum pada Siswa Kelas XII IPA4 SMA Negeri 2 Kebumen,” 2014, no. April, pp. 149-152.

[18] Yani, M. Amin, F. Rohman, and E. Suarsini, "The behavior of the coastal area Lake Tempe against the deterioration of the water quality and its control strategy," in Seminar Nasional Biologi Universitas Hasanuddin Makassar, 2018, pp. 156-165.

[19] P. P. Dharsini and Sharpipudin, "Bioremediation of Industrial and Municipal Waste Water Using Bacterial Isolates,” Int. J. Eng. Sci. Res. Technol., vol. 5, no. 5, pp. 173-177, 2016.

[20] D. T. Widayati et al., Pedoman Umum Pembelajaran Berbasis Riset (PUPBR) Universitas. Yogyakarta: Universitas Gaja Mada, 2010.

[21] N. Primian, "Pengembangan Buku Ajar Berbasis Penelitian Bahan Alam Lokal Sebagai Estrogenik pada Mata Kuliah Fisiologi Hewan,” Pros. Math. Sci., pp. 407-4010, 2014.

[22] E. Peniati and Parmin, "Pengembangan Modul Mata Kuliah Strategi Belajar Mengajar Ipa Berbasis Hasil Penelitian Pembelajaran,” Jpii, vol. 1, no. 1, pp. 8-15, 2012.

[23] M. Embong, A. M. Noor, H. M. Hashim, R. M. Ali, and Z. H. Shaari, "E-Books as Textbooks in the Classroom," Procedia - Soc. Behav. Sci., vol. 47, pp. 1802-1809, 2012.

[24] M. Amin, "Implementasi Hasil-Hasil Penelitian Bidang Biologi Dalam Pembelajaran," in Seminar Nasional Pendidikan Biologi FKIP UNS, 2010, pp. 12-18.

[25] Yani and R. Adiansyah, "Developing Problem-Based Learning Module For Biotechnology Concepts," J. Pendidik. Sains, vol. 5, no. 2, pp. 46-56, 2017.

[26] Y. H. Adisedjaja, "Peranan Praktikum Dalam Mengembangkan Keterampilan Proses Dan Kerja Laboratorium," in MGMP Biologi Kabupaten Garut, 2009, pp. 1-7.

[27] Yuwono, “Optimalisasi Web Internet Sebagai Usaha Peningkatan Kemampuan Menulis,” Lingua, vol. V, no. 1, pp. 73-83, 2009.

[28] M. Amin, "Perkembangan biologi dan tantangan pembelajarannya," in Seminar Nasional Pendidikan dan Saintek, 2016, vol. 2016, pp. 1-11.

\section{AUTHORS' BIOGRAPHY}

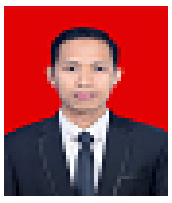

Ahmad Yani is currently teaching at the Biology Education Program, Faculty of Teacher Training and Education Universitas Puangrimaggalatung Sengkang, Indonesia. The scientific field of Biological Education. The research area, which is currently involved in the development of scientific content in environmental microbiology, is being integrated into educational products such as research-based teaching materials and book reference based on research for pre-service biology teacher.

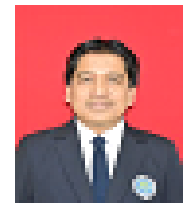

Mohamad Amin is a lecturer at the Faculty of Mathematics and Natural Sciences, Universitas Negeri Malang, Indonesia. Field of science Molecular genetics and education. Has published several articles in international journals in the field of molecular gentika and issues of biology education in learning

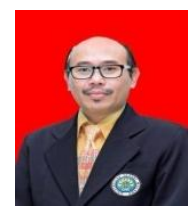

Fatchur Rohman is a lecturer at the Faculty of Mathematics and Natural Sciences, Universitas Negeri Malang, Indonesia. Science field Environmental ecology and education. Has published several articles in international journals in the field of affairs 
and issues of biology education in learning

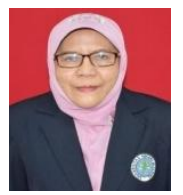

Endang Suarsini is a lecturer at the Faculty of Mathematics and Natural Sciences, Universitas Negeri Malang, Indonesia. Scientific field of Microbiology and education. Several articles have been published in international journals in the field of microbiology and issues of biology education in learning

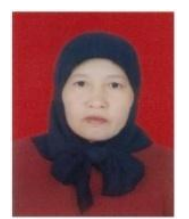

Sahriah is currently teaching at the Biology Education Program, Faculty of Teacher Training and Education Universitas Puangrimaggalatung Sengkang, Indonesia. Scientific field of biology education. The field of research currently being applied is the application of learning models and the development of teaching materials

Citation: Ahmad Yani, "Profile of Teaching Materials Environment Biology and Ability Pre-service Biology Teacher to Communicate Laboratory Report". International Journal of Humanities Social Sciences and Education (IJHSSE), vol 6, no. 3, 2019, pp. 33-39. doi: http://dx.doi.org/10.20431/2349-0381.0603005.

Copyright: () 2019 Authors. This is an open-access article distributed under the terms of the Creative Commons Attribution License, which permits unrestricted use, distribution, and reproduction in any medium, provided the original author and source are credited. 